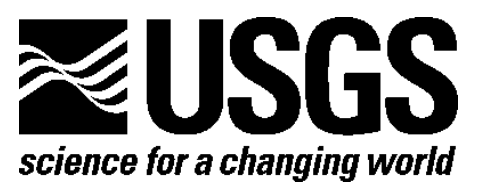

\title{
Multi-Elemental Analysis of Aqueous Geological Samples by Inductively Coupled Plasma-Optical Emission Spectrometry
}

Open-File Report 2014-1067 


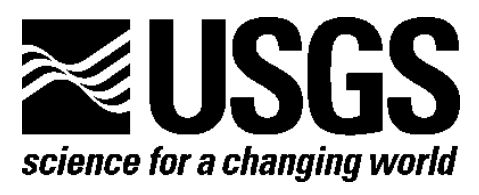

\section{Multi-Elemental Analysis of Aqueous Geological Samples by Inductively Coupled Plasma-Optical Emission Spectrometry}

By Todor I. Todorov, Ruth E. Wolf, and Monique Adams

Open-File Report 2014-1067 


\section{U.S. Department of the Interior \\ SALLY JEWELL, Secretary}

\section{U.S. Geological Survey \\ Suzette M. Kimball, Acting Director}

U.S. Geological Survey, Reston, Virginia: 2014

For more information on the USGS-the Federal source for science about the Earth,

its natural and living resources, natural hazards, and the environment-visit

http://www.usgs.gov or call 1-888-ASK-USGS

For an overview of USGS information products, including maps, imagery, and publications, visit $h$ ttp://www.usgs.gov/pubprod

To order this and other USGS information products, visit http://store.usgs.gov

Any use of trade, firm, or product names is for descriptive purposes only and does not imply endorsement by the U.S. Government.

Although this information product, for the most part, is in the public domain, it also may contain copyrighted materials as noted in the text. Permission to reproduce copyrighted items must be secured from the copyright owner.

Suggested citation:

Todorov, T.I., Wolf, R.E., and Adams, Monique, 2014, Multi-elemental analysis of aqueous geological samples by inductively coupled plasma-optical emission spectrometry: U.S. Geological Survey Open-File Report 2014-1067, 21 p., http://dx.doi.org/10.3133/ofr20141067.

ISSN 2331-1258 (online) 


\section{Contents}

Principle

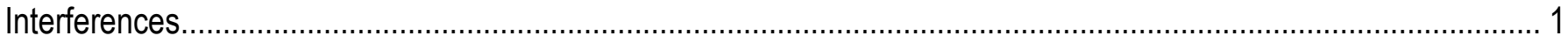

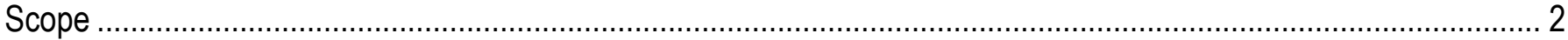

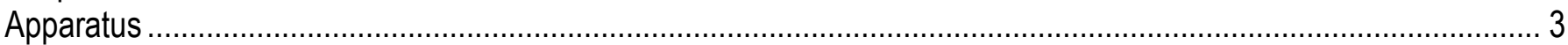

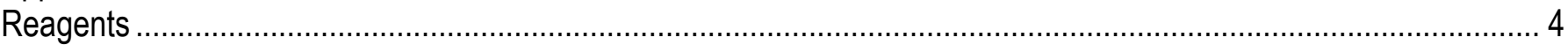

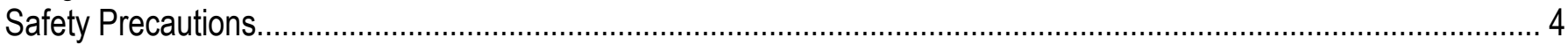

Sample Preparation

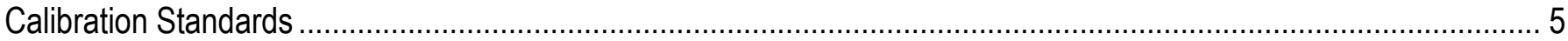

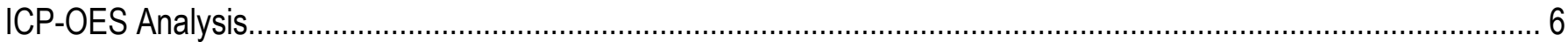

Method Performance -Blank Analysis and Reporting Limits.......................................................................... 8

Method Performance-Analyses of CRMs and Duplicate Samples...................................................................12

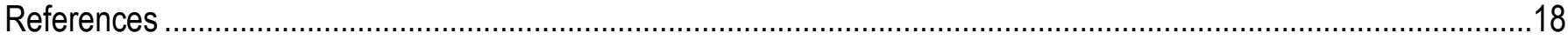

Appendix 1. Generation of Multicomponent Spectral Fitting (MSF) and Interelement Correction Factors (IEC)

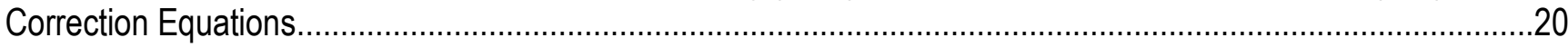

\section{Tables}

Table 1. Elements and wavelengths for ICP-OES analysis ................................................................... 3

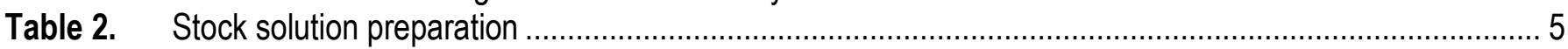

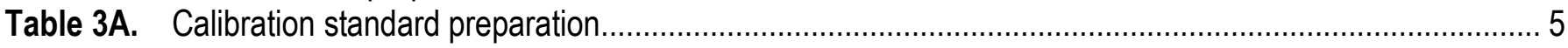

Table 3B. Calibration standard concentrations ......................................................................................... 5

Table 4. Instrument parameters and conditions for the determination of 28 elements in aqueous

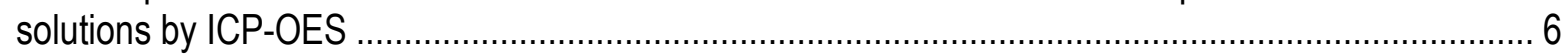

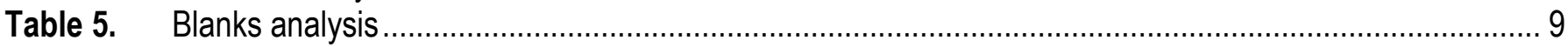

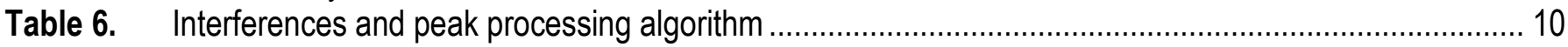

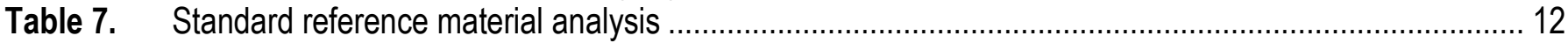

Table 8. Duplicate analysis, based on the analyses of 71 duplicate pairs ...................................................... 18

\section{Conversion Factors}

SI to Inch/Pound

\begin{tabular}{lcl}
\hline & Multiply & \\
\hline & Length & To obtain \\
\hline centimeter $(\mathrm{cm})$ & 0.3937 & inch (in.) \\
millimeter $(\mathrm{mm})$ & 0.03937 & inch (in.) \\
\hline & Volume & \\
\hline liter $(\mathrm{L})$ & 33.82 & ounce, fluid (fl. oz) \\
\hline & Flow rate & \\
\hline liter per second (L/s) & 15.85 & gallon per minute (gal/min) \\
\hline & Mass & \\
\hline gram $(\mathrm{g})$ & 0.03527 & ounce, avoirdupois (oz) \\
kilogram $(\mathrm{kg})$ & 2.205 & pound avoirdupois (lb) \\
\hline
\end{tabular}

Concentrations of chemical constituents are given either in milligrams per liter (mg/L) or micrograms per liter ( $\mu \mathrm{g} / \mathrm{L})$. 


\title{
Multi-Elemental Analysis of Aqueous Geological Samples by Inductively Coupled Plasma-Optical Emission Spectrometry
}

\author{
By Todor I. Todorov ${ }^{1}$, Ruth E. Wolf2, and Monique Adams²
}

\section{Principle}

Typically, 27 major, minor, and trace elements are determined in natural waters, acid mine drainage, extraction fluids, and leachates of geological and environmental samples by inductively coupled plasma-optical emission spectrometry (ICP-OES). At the discretion of the analyst, additional elements may be determined after suitable method modifications and performance data are established. Samples are preserved in 1-2 percent nitric acid $\left(\mathrm{HNO}_{3}\right)$ at sample collection or as soon as possible after collection. The aqueous samples are aspirated into the ICP-OES discharge, where the elemental emission signals are measured simultaneously for 27 elements. Calibration is performed with a series of matrix-matched, multi-element solution standards.

\section{Interferences}

ICP-OES interferences may result from spectral interferences, background shifts, and matrix effects (Thompson and Walsh, 1983). Interelement correction factors (IECs) and background corrections are applied using PerkinElmer WinLab 32 version 4.0 proprietary data system software (Boss and Fredeen, 2004). Either one-point or two-point background correction is selected for all wavelengths determined by peak area or peak height measurements based on adjacent spectral features. Approximately 80 spectral interference corrections are performed on each sample. Further corrections are made when an element influences other elements beyond the normal range of correction. It is allowable, at the analyst's discretion, to not report an element affected by the extraordinary interference of another element or to flag its data as being estimated as a result of the interference. Interference corrections are generally made using the proprietary multicomponent spectral fitting (MSF) algorithm provided in the instrument operating software (Ivaldi and Barnard, 1993). Multicomponent spectral fitting requires that the two lines do not completely overlap. The MSF algorithm can correct the interference in a wide range of concentrations and analyte-to-interferent ratios. The MSF correction factors must be checked and regenerated on an annual basis or whenever significant instrument or method changes are made. Additionally, new MSF corrections should be generated every time a wavelength calibration is performed (not common unless the instrument is physically moved or a hardware problem is experienced). See appendix 1 for a detailed procedure explaining generation of new MSF correction factors.

\footnotetext{
${ }^{1}$ U.S. Department of Health and Human Services, Food and Drug Administration

${ }^{2}$ U.S. Geological Survey
} 
All analyses are performed using internal standardization (Boss and Fredeen, 2004). In this procedure, a known amount of the selected internal standardization element is added to all blanks, standards, and samples presented to the ICP-OES instrument. The ratios of the resulting analytical signals for each element of interest to the measured intensity of the internal standard element are then calculated. The purpose of the internal standard is twofold: (1) to compensate for instrument drift due to changes of the sample introduction system over time (for example, nebulizer or injector clogging and tubing degradation), and (2) to compensate for differences in sample matrix characteristics (for example, viscosity and ionization efficiency) that may affect sample uptake rates or ionization efficiencies. The internal standard element is selected by determining which element is a good proxy for the elements of interest, and it cannot be present to any significant extent in the samples or be one of the elements of interest. To use internal standardization, the internal standard element must be added to the calibration blanks, standards, and samples at the same concentration. Generally, internal standards are added online using a mixing tee in order to facilitate high-throughput analysis, reduce analyst time preparing individually spiked standards and samples, eliminate errors caused by spiking, and minimize the amount of internal standard used. However, the use of online internal standardization can cause undesirable dilution of the sample and the analyst may choose instead to individually and manually spike all solutions with the internal standard solution.

\section{Scope}

Analysis by ICP-OES for major and minor elements in aqueous samples is useful for a variety of geochemical investigations. The wavelengths used for this method, including those monitored for interference effects, are shown in table 1. Approximately 200 aqueous samples can be analyzed in 27 hours by the ICP-OES instrumentation. 
Table 1. Elements and wavelengths for ICP-OES analysis.

[nm, nanometer; a, axial detection; $\mathrm{r}$, radial detection; Lu, Lutetium was used as an internal standard]

\begin{tabular}{|c|c|}
\hline Element & Wavelength, $\mathrm{nm}$ \\
\hline $\mathrm{Ag}$ & 328.066 (a), 338.288 (a) \\
\hline $\mathrm{Al}$ & $396.151(\mathrm{r}), 308.212(\mathrm{r})$ \\
\hline As & $188.980(\mathrm{r}), 193.696(\mathrm{r}, \mathrm{a})$ \\
\hline B & $249.772(\mathrm{r}), 249.676(\mathrm{r})$ \\
\hline $\mathrm{Ba}$ & $455.402(\mathrm{r}), 233.524(\mathrm{r})$ \\
\hline $\mathrm{Be}$ & $313.104(\mathrm{r}), 313.042(\mathrm{r})$ \\
\hline $\mathrm{Ca}$ & $317.932(r), 422.673(r)$ \\
\hline $\mathrm{Cd}$ & $226.502(\mathrm{a}), 214.434(\mathrm{a})$ \\
\hline Co & 228.615 (a), 230.785 (r) \\
\hline $\mathrm{Cr}$ & $205.560(\mathrm{a}), 267.711(\mathrm{r})$ \\
\hline $\mathrm{Cu}$ & $324.754(\mathrm{r}), 327.393$ (a) \\
\hline $\mathrm{Fe}$ & $238.201(\mathrm{r}), 239.568(\mathrm{a})$ \\
\hline $\mathrm{K}$ & $766.490(\mathrm{r})$ \\
\hline $\mathrm{Li}$ & $670.784(\mathrm{r})$ \\
\hline $\mathrm{Mg}$ & $285.212(\mathrm{r}), 279.076(\mathrm{r})$ \\
\hline $\mathrm{Mn}$ & $257.607(\mathrm{r}), 293.305(\mathrm{r})$ \\
\hline Mo & 202.032 (a), 203.846 (a) \\
\hline $\mathrm{Na}$ & $589.587(\mathrm{r}), 330.237(\mathrm{r})$ \\
\hline $\mathrm{Ni}$ & $231.604(\mathrm{r}, \mathrm{a})$ \\
\hline $\mathrm{P}$ & $213.617(\mathrm{r}), 178.224(\mathrm{r})$ \\
\hline $\mathrm{Pb}$ & $220.354(\mathrm{r}, \mathrm{a})$ \\
\hline$S^{2}$ & $180.671(\mathrm{a}), 181.975(\mathrm{a})$ \\
\hline $\mathrm{Sb}$ & $206.834(\mathrm{a}), 217.582(\mathrm{r})$ \\
\hline $\mathrm{Se}^{1}$ & $196.029(\mathrm{r}, \mathrm{a})$ \\
\hline $\mathrm{Si}$ & $251.609(\mathrm{r}), 221.663(\mathrm{r})$ \\
\hline $\mathrm{Sr}$ & $421.549(\mathrm{r}), 460.733(\mathrm{r})$ \\
\hline $\mathrm{Th}^{1}$ & $283.730(\mathrm{r}), 401.913(\mathrm{r})$ \\
\hline $\mathrm{Ti}^{1}$ & $334.943(\mathrm{r}), 368.519(\mathrm{r})$ \\
\hline $\mathrm{Tl}^{1}$ & $190.801(\mathrm{r})$ \\
\hline $\mathrm{V}$ & 292.402 (a), $290.880(\mathrm{r})$ \\
\hline $\mathrm{U}^{1}$ & $409.014(\mathrm{a}, \mathrm{r})$ \\
\hline $\mathrm{W}^{1}$ & $207.912(r), 239.708(r)$ \\
\hline $\mathrm{Zn}$ & 213.858 (a), 206.199 (a) \\
\hline $\mathrm{Lu}$ & $291.138(\mathrm{r}, \mathrm{a})$ \\
\hline
\end{tabular}

${ }^{1}$ Monitored for interference, not reported

${ }^{2} \mathrm{~S}$ is reported as sulfate $\left(\mathrm{SO}_{4}\right)$

\section{Apparatus}

- Simultaneous dual-view ICP-OES system equipped with an autosampler (PerkinElmer Optima 5300DV, PerkinElmer, Waltham, Mass., or equivalent)

- Burgener PEEK MiraMist Nebulizer PMM 4000 (Burgener Research, Inc., Mississauga, Ontario, Canada) 
- 13 x 100 millimeter $(\mathrm{mm})$ disposable, polypropylene test tubes with caps (VWR International, vials part number 60818-860 and caps part number 60828-738)

- Adjustable mechanical or electronic pipettes, typical volume ranges needed are 5-120 microliters $(\mu \mathrm{L}), 50-1,000 \mu \mathrm{L}$, and $100-5,000 \mu \mathrm{L}$

- 15 and 50 milliliter (mL) BD Falcon polypropylene tubes (BD Biosciences, San Jose, Calif.).

- Peristaltic pump tubing, polyvinyl chloride (PVC) type (Meinhard Inc., Golden, Colo.):

- Internal standard: Green-orange (0.38 mm inner diameter [i.d.])

- Sample: Black-black (0.76 mm i.d.)

- Drain: Red-red (1.14 mm i.d.)

- Autosampler peristaltic pump tubing, Santoprene type: Red-red (1.14 mm i.d.), 3-stop (Meinhard Inc., Golden, Colo.)

- Plastic mixing tee (1/16" i.d.) (EW-30506-15), (Cole-Parmer, Vernon Hills, Ill.)

- 20 milligrams per liter (mg/L) Lu internal standard solution (High Purity Standards, Charleston, S.C.)

\section{Reagents}

- Concentrated nitric acid, $\mathrm{HNO}_{3}$, reagent grade, 70 percent weight/weight (wt/wt) for rinse solution preparation (VWR International, Radnor, Pa.)

- Concentrated ultra-pure double distilled $\mathrm{HNO}_{3}, 70$ percent wt/wt, prepared via sub-boiling distillation (Reagent grade $\mathrm{HNO}_{3}$, VWR International, Radnor, Pa., purified using Milestone DuoPur, Mileston, Shelton, Conn.)

- Deionized water (DI), 18 megohm (M $\Omega$ ) (Milli-Q, EMD Millipore, Billerica, Mass.)

- 2 percent weight/volume (wt/vol) nitric acid solution: $56 \mathrm{~mL}$ double distilled 70 percent $\mathrm{HNO}_{3}$ diluted to $2,000 \mathrm{~mL}$ using DI water

- Single element standards: 10,000 mg/L of Al, Ca, Fe, K, Mg, Na, and 1,000 mg/L of Ag, As, B, Ba, $\mathrm{Be}, \mathrm{Bi}, \mathrm{Cd}, \mathrm{Co}, \mathrm{Cr}, \mathrm{Cu}, \mathrm{Li}, \mathrm{Lu}, \mathrm{Mn}, \mathrm{Mo}, \mathrm{Ni}, \mathrm{P}, \mathrm{Pb}, \mathrm{S}, \mathrm{Sb}, \mathrm{Se}, \mathrm{Si}, \mathrm{Sr}, \mathrm{Th}, \mathrm{Ti}, \mathrm{Tl}, \mathrm{U}, \mathrm{V}, \mathrm{W}, \mathrm{Zn}$, and Zr (High Purity Standards, Charleston, S.C.)

- Lutetium internal standard solution (20 mg/L Lu): 40.30 grams (g) 1,000 mg/L Lu diluted in 100 $\mathrm{mL}$ double distilled 70 percent $\mathrm{HNO}_{3}$ and $1,860 \mathrm{~mL}$ DI water.

\section{Safety Precautions}

All laboratory personnel are required to wear safety glasses, gloves, closed toe shoes, and lab coats when working in the laboratory. Refer to the laboratory chemical hygiene plan and material safety data sheets for specific precautions, effects of overexposure, and first-aid treatment for reagents used in the preparation procedure and operation of the ICP-OES system.

\section{Sample Preparation}

Samples need to be preserved in 1-2 percent $\mathrm{wt} / \mathrm{vol} \mathrm{HNO}_{3}$ at sample collection or as soon as possible after sample collection. Most sampling protocols require that the samples are filtered and acidified in the field (USGS, 2006; Wanty, 1999; Wilde, 2004). At the analyst's discretion, unfiltered samples collected as raw acidified (RA) may be filtered or decanted prior to analysis if visible particulates or solids are present to prevent clogging of the sample introduction system (for example, sample probe or nebulizer). The analyst should notify the sample submitter if this or any other 
procedures were necessary to analyze the samples. If a sample result is over the range of the calibration curve, dilution and re-analysis of the sample(s) for the over range elements are required.

\section{Calibration Standards}

All calibration standards are prepared in 2 percent $\mathrm{HNO}_{3}$ starting with 10,000 $\mathrm{mg} / \mathrm{L}$ or 1,000 $\mathrm{mg} / \mathrm{L}$ single-element solutions using six stock solutions (table 2). The final volume required is $50 \mathrm{~mL}$ for all calibration standard solutions. The preparation and concentrations of the calibration standards are shown in tables $3 \mathrm{a}$ and $3 \mathrm{~b}$, respectively. Alternatively, final calibration standards may be prepared using commercially available or custom-mixed multi-element standards.

\section{Table 2. Stock solution preparation.}

$\left[\mathrm{mg} / \mathrm{L}\right.$, milligrams per liter; $\mathrm{mL}$, milliliter; \%, percent; $\mathrm{HNO}_{3}$, nitric acid; all concentrations in mg/L; final standard volume is $50 \mathrm{~mL}]$

\section{Stock 1 preparation}

$2.5 \mathrm{~mL}$ each of $1,000 \mathrm{mg} / \mathrm{L}$ high purity standard solution of $\mathrm{As}, \mathrm{Cu}, \mathrm{Mn}, \mathrm{Mo}, \mathrm{Pb}, \mathrm{Si}, \mathrm{Zn}, \mathrm{P}, \mathrm{S}$

$0.25 \mathrm{~mL}$ each of $1,000 \mathrm{mg} / \mathrm{L}$ high purity standard solution of $\mathrm{Ag}, \mathrm{B}, \mathrm{Ba}$,

$\mathrm{Be}, \mathrm{Bi}, \mathrm{Cd}, \mathrm{Co}, \mathrm{Cr}, \mathrm{Li}, \mathrm{Ni}, \mathrm{Sb}, \mathrm{Se}, \mathrm{Sr}, \mathrm{Th}, \mathrm{Ti}, \mathrm{Tl}, \mathrm{U}, \mathrm{V}, \mathrm{W}, \mathrm{Zr}$

Add $6 \mathrm{~mL}$ of concentrated distilled $\mathrm{HNO}_{3}$

Dilute to $50 \mathrm{~mL}$ with $2 \%$ nitric acid

\begin{tabular}{|c|}
\hline Stock 2 preparation \\
\hline $\begin{array}{l}1 \mathrm{~mL} \text { Stock } 1 \\
\text { Dilute to } 50 \mathrm{~mL} \text { with } 2 \% \mathrm{HNO}_{3}\end{array}$ \\
\hline Stock 3 preparation \\
\hline $\begin{array}{l}5 \mathrm{~mL} \text { each of } 10,000 \mathrm{mg} / \mathrm{L} \text { high purity standard solution of } \mathrm{Ca}, \mathrm{K}, \mathrm{Mg}, \mathrm{Na} \\
\text { Dilute to } 50 \mathrm{~mL} \text { with } 2 \% \mathrm{HNO}_{3}\end{array}$ \\
\hline $\begin{array}{l}\text { Stock } 4 \text { preparation } \\
\end{array}$ \\
\hline $\begin{array}{l}2.5 \mathrm{~mL} \text { Stock } 3 \\
\text { Dilute to } 50 \mathrm{~mL} \text { with } 2 \% \mathrm{HNO}_{3}\end{array}$ \\
\hline Stock 5 preparation \\
\hline $\begin{array}{l}5 \mathrm{~mL} \text { each of } 10,000 \mathrm{mg} / \mathrm{L} \text { high purity standard solution of } \mathrm{Al}, \mathrm{Fe} \\
\text { Dilute to } 50 \mathrm{~mL} \text { with } 2 \% \mathrm{HNO}_{3}\end{array}$ \\
\hline $\begin{array}{l}\text { Stock } 6 \text { preparation } \\
\end{array}$ \\
\hline $\begin{array}{l}0.1 \mathrm{~mL} \text { Stock } 5 \\
\text { Dilute to } 50 \mathrm{~mL} \text { with } 2 \% \mathrm{HNO}_{3}\end{array}$ \\
\hline
\end{tabular}

Table 3A. Calibration standard preparation.

[mL, milliliter; \%, percent; $\mathrm{HNO}_{3}$, nitric acid; $\mathrm{mg} / \mathrm{L}$, milligrams per liter]

\begin{tabular}{|c|c|c|c|c|c|c|c|}
\hline \multicolumn{8}{|c|}{ Volume of stock solutions $(\mathrm{mL})$ to prepare $50 \mathrm{~mL}$ calibration standard } \\
\hline & Stock 1 & Stock 2 & Stock 3 & Stock 4 & Stock 5 & Stock 6 & $2 \% \mathrm{HNO}_{3}$ \\
\hline Standard 1 & & 0.5 & & 1 & & 0.25 & 48.25 \\
\hline Standard 2 & & 2 & & 4 & & 1 & 43 \\
\hline Standard 3 & & 10 & 1 & & & 5 & 34 \\
\hline Standard 4 & 1 & & 2.5 & & 0.1 & & 46.4 \\
\hline Standard 5 & 10 & & 5 & & 5 & & 30 \\
\hline
\end{tabular}


Table 3B. Calibration standard concentrations.

[mg/L, milligrams per liter]

\begin{tabular}{|c|c|c|c|c|c|}
\hline \multirow[b]{2}{*}{ Element } & \multicolumn{5}{|c|}{ Standard concentration, $\mathrm{mg} / \mathrm{L}$} \\
\hline & Standard 1 & Standard 2 & Standard 3 & Standard 4 & Standard \\
\hline $\mathrm{Ag}$ & 0.001 & 0.004 & 0.02 & 0.1 & 1 \\
\hline $\mathrm{Al}$ & 0.01 & 0.04 & 0.2 & 2 & 100 \\
\hline As & 0.01 & 0.04 & 0.2 & 1 & 10 \\
\hline B & 0.001 & 0.004 & 0.02 & 0.1 & 1 \\
\hline $\mathrm{Ba}$ & 0.001 & 0.004 & 0.02 & 0.1 & 1 \\
\hline $\mathrm{Be}$ & 0.001 & 0.004 & 0.02 & 0.1 & 1 \\
\hline $\mathrm{Bi}$ & 0.001 & 0.004 & 0.02 & 0.1 & 1 \\
\hline $\mathrm{Ca}$ & 1 & 4 & 20 & 50 & 100 \\
\hline $\mathrm{Cd}$ & 0.001 & 0.004 & 0.02 & 0.1 & 1 \\
\hline Co & 0.001 & 0.004 & 0.02 & 0.1 & 1 \\
\hline $\mathrm{Cr}$ & 0.001 & 0.004 & 0.02 & 0.1 & 1 \\
\hline $\mathrm{Cu}$ & 0.01 & 0.04 & 0.2 & 1 & 10 \\
\hline $\mathrm{Fe}$ & 0.01 & 0.04 & 0.2 & 2 & 100 \\
\hline K & 1 & 4 & 20 & 50 & 100 \\
\hline $\mathrm{Li}$ & 0.001 & 0.004 & 0.02 & 0.1 & 1 \\
\hline $\mathrm{Mg}$ & 1 & 4 & 20 & 50 & 100 \\
\hline $\mathrm{Mn}$ & 0.01 & 0.04 & 0.2 & 1 & 10 \\
\hline Mo & 0.01 & 0.04 & 0.2 & 1 & 10 \\
\hline $\mathrm{Na}$ & 1 & 4 & 20 & 50 & 100 \\
\hline $\mathrm{Ni}$ & 0.001 & 0.004 & 0.02 & 0.1 & 1 \\
\hline $\mathrm{P}$ & 0.01 & 0.04 & 0.2 & 1 & 10 \\
\hline $\mathrm{Pb}$ & 0.01 & 0.04 & 0.2 & 1 & 10 \\
\hline$S^{1}$ & 0.01 & 0.04 & 0.2 & 1 & 10 \\
\hline $\mathrm{Sb}$ & 0.001 & 0.004 & 0.02 & 0.1 & 1 \\
\hline $\mathrm{Se}$ & 0.001 & 0.004 & 0.02 & 0.1 & 1 \\
\hline $\mathrm{Si}$ & 0.01 & 0.04 & 0.2 & 1 & 10 \\
\hline $\mathrm{Sr}$ & 0.001 & 0.004 & 0.02 & 0.1 & 1 \\
\hline Th & 0.001 & 0.004 & 0.02 & 0.1 & 1 \\
\hline $\mathrm{Ti}$ & 0.001 & 0.004 & 0.02 & 0.1 & 1 \\
\hline $\mathrm{Tl}$ & 0.001 & 0.004 & 0.02 & 0.1 & 1 \\
\hline $\mathrm{U}$ & 0.001 & 0.004 & 0.02 & 0.1 & 1 \\
\hline $\mathrm{V}$ & 0.001 & 0.004 & 0.02 & 0.1 & 1 \\
\hline W & 0.001 & 0.004 & 0.02 & 0.1 & 1 \\
\hline $\mathrm{Zn}$ & 0.01 & 0.04 & 0.2 & 1 & 10 \\
\hline $\mathrm{Zr}$ & 0.001 & 0.004 & 0.02 & 0.1 & 1 \\
\hline
\end{tabular}

${ }^{1} \mathrm{~S}$ is reported as sulfate $\left(\mathrm{SO}_{4}\right)$

\section{ICP-OES Analysis}

Table 4 shows instrumental operating conditions for this method using a PerkinElmer Optima 5300DV. The elemental wavelengths and viewing position are given in table 1 . All analyses are performed using online internal standardization. The internal standard solution delivered from the orange-green $(0.38$ $\mathrm{mm}$ i.d.) peristaltic pump tubing is mixed with the sample solutions coming from the black-black $(0.76$ mm i.d.) tubing using a polypropylene barbed tee-fitting (Cole Parmer, EW-30506-15) prior to 
introduction into the nebulizer. The internal standard is diluted by a 1:4 ratio, resulting in a Lu internal standard concentration of approximately $5 \mathrm{mg} / \mathrm{L}$. The sample flow rate is set to 0.8 milliliter per minute $(\mathrm{mL} / \mathrm{min})$ in the instrument software.

Table 4. Instrument parameters and conditions for the determination of 27 elements in aqueous solutions by ICP-OES.

[W, watts; L/min, liters per minute; $\mathrm{mL} / \mathrm{min}$, milliliters per minute; $\mathrm{mm}$, millimeters; i.d., inner diameter; $\mathrm{s}$, seconds]

\begin{tabular}{ll}
\hline \multicolumn{1}{c}{ Instrument parameters } & \multicolumn{1}{c}{ Conditions } \\
\hline RF power & $1450 \mathrm{~W}$ \\
Cool gas $(\mathrm{L} / \mathrm{min})$ & 13 \\
Auxilary gas $(\mathrm{L} / \mathrm{min})$ & 0.4 \\
Nebulizer gas $(\mathrm{L} / \mathrm{min})$ & $0.60-0.68$ \\
Injector & $2 \mathrm{~mm}$ quartz \\
Spray chamber & Cyclonic, quartz \\
Sample flow $(\mathrm{mL} / \mathrm{min})($ black/black tubing, $0.76 \mathrm{~mm}$ i.d.) & 0.8 \\
Integration time (s) & 0.1 to 10 (Auto) \\
Nebulizer & Burgener PEEK Mira Mist \\
Rinse time (s) & 120 at $2 \mathrm{~mL} /$ min uptake rate \\
Specific method name & water02TT 20120711 \\
\hline
\end{tabular}

Once a 30-minute warm-up time has been completed after plasma ignition, the instrument sensitivity is checked while aspirating a 2 percent $\mathrm{HNO}_{3}$ solution mixed with the $20 \mathrm{mg} / \mathrm{L} \mathrm{Lu}$ internal standard solution using the online tee fitting. The method minimum specification for the Lu signal is 20,000 counts-per-second (cps) for radial and 150,000 cps for axial detection mode. The sensitivity requirements must be met for both modes since elements are analyzed in both radial and axial detection modes. The sensitivity readings should be recorded in the instrument logbook. If the minimum sensitivities are not met, corrective action must be taken before sample analyses are continued. The most common causes of low sensitivity include: worn or improperly tensioned pump tubing, clogging of the nebulizer, partial clogging of the torch injector, or improper positioning of radial viewing height or axial viewing position.

The ICP-OES instrument is calibrated at the start of each analytical run using a blank and five multi-element solution standards (see table 3) using a linear through zero calibration. The calibration blank should be prepared from the same source and at the same acid concentration used in the calibration standards. Blank subtraction is performed to negate the effect of the reagents in instances where the blank is higher than the detection limit. The performance of the method is checked using a minimum of three aqueous quality control samples or certified reference materials (CRMs) available from USGS Standard Reference Sample Project (http://bqs.usgs.gov/srs/), the National Institutes for Standards and Technology (NIST, http://www.nist.gov), and various other reference materials suppliers. Calibration is verified using the independent calibration verification (ICV) standard(s) prepared from a second, independent source of stock solutions. The ICV solution should be prepared at a level near the mid-point of the calibration curve for each element; for example, $25.5 \mathrm{mg} / \mathrm{L} \mathrm{Ca}, \mathrm{Na} ; 5.5 \mathrm{mg} / \mathrm{L} \mathrm{K}, \mathrm{Mg}$, $\mathrm{Si}$; and $0.5 \mathrm{mg} / \mathrm{L} \mathrm{Ag}, \mathrm{Al}, \mathrm{As}, \mathrm{B}, \mathrm{Be}, \mathrm{Ba}, \mathrm{Cd}, \mathrm{Co}, \mathrm{Cu}, \mathrm{Cr}, \mathrm{Fe}, \mathrm{Li}, \mathrm{Mn}, \mathrm{Mo}, \mathrm{Ni}, \mathrm{Pb}, \mathrm{S}, \mathrm{Sb}, \mathrm{Sr}, \mathrm{V}, \mathrm{Zn}$, and P. The measured ICV concentrations should be within \pm 10 percent of the true or prepared value. If the ICV results are not within acceptable limits, then the source of the error should be identified and 
corrected and the instrument recalibrated and the ICV solution(s) reanalyzed. Common errors include improperly prepared calibration standards or stock solutions. The results for all quality control sample or CRM sample analyses should be within \pm 20 percent of the certified or proposed values, including stated errors. If the results are not within \pm 20 percent of the stated values, the samples are prepared again and re-analyzed by ICP-OES. If the results are still not within acceptable values, the instrument conditions and method parameters are checked and the instrument is re-calibrated using freshly prepared calibration standards and the quality control samples are reanalyzed. For every 10 unknown samples, a blank, continuous calibration verification (CCV), and a CRM sample is analyzed. The CCV solution is prepared from the same stock standards used to prepare the calibration standards and has the same concentration as the ICV solution (see above). The measured CCV concentrations should be within \pm 10 percent of the true or prepared value. If the $\mathrm{CCV}$ values are not within limits, the instrument conditions and method parameters are checked and the instrument is re-calibrated using freshly prepared calibration standards, and any quality control and unknown samples are re-analyzed. If the CRM sample is not within \pm 20 percent of the accepted value, the instrument conditions and method parameters are checked and the instrument is re-calibrated using freshly prepared calibration standards, and any quality control and unknown samples are re-analyzed.

\section{Method Performance-Blank Analysis and Reporting Limits}

The instrument detection limits and reporting limits are shown in table 5. The preferred wavelengths are selected based on background equivalent concentration (BEC), achieved detection limits, analytical performance of CRMs, and minimal interferences present at the particular wavelength. For most elements, more than one wavelength is analyzed in order to rule out possible interferences in unusual samples. The results for $\mathrm{Si}$ and $\mathrm{S}$ are converted to $\mathrm{SiO}_{2}$ and $\mathrm{SO}_{4}{ }^{2-}$ using 2.14 and 2.995 conversion factors, respectively. The dual-view instrument used in this report offers the capability of detecting the elements in the plasma radially and axially. Axial detection provides a longer viewing distance of only the central channel where the analytes are in the plasma, and thus, it is more sensitive and provides improved sensitivity compared to radial or side-on view. The improvement of detection limits in clean samples (for example, drinking water) is on the order of 5-10 times. The main disadvantage of axial view is in cases with increased total dissolved solids (for example, natural waters from mine drainange, bore holes, and leachates). As the matrix is increased, the analytes of interest signal can be decreased or increased resulting in an inaccurate quantification (Alavosus, 1995). For example, $\mathrm{Cu}$ is analyzed at 324.754 (radial) and 327.393 (axial). The BEC for the two wavelengths are $0.18 \mu \mathrm{g} / \mathrm{L}$ and $0.32 \mu \mathrm{g} / \mathrm{L}$, respectively (PerkinElmer, 2010, Winlab 32 Software, version 4.0). Although the 324.754 line provides better BEC, it has interferences from Mg and Th and requires the use of MSF corrections in order to achieve accurate quantification. Additionally, matrix effects from the major cations in waters are significant, and the use of radial detection is advantageous. Thus, the less sensitive $\mathrm{Cu}$ line at 327.393 provides better actual detection limits, and because of the lack of interferences, it is the preferred wavelength in this method. Similar reasoning is behind the selection of the preferred analytical wavelengths for all other analytes in this investigation. In table 5, the method detection limit (MDL) is calculated as a value three times the standard deviation (SD) of a large number $(n=30)$ of blank analyses over time. The lower reporting limit in table 5 is established by multiplying the MDL by a reasonable value, generally between 2 and 10, and rounding to a suitable number of significant figures. The instrument MDLs and reporting limits should be re-evaluated on an annual basis or as instrument operating conditions are changed. 
Table 5. Blanks analysis.

[SD, standard deviation; MDL, method detection limit; $\mu \mathrm{g} / \mathrm{L}$, micrograms per liter; mg/L, milligrams per liter; preferred lines are in bold]

\begin{tabular}{|c|c|c|c|c|c|c|c|c|}
\hline $\begin{array}{l}\text { Element and } \\
\text { wavelength }\end{array}$ & $\begin{array}{l}\text { Detection } \\
\text { view }\end{array}$ & $\begin{array}{c}\text { Calibration } \\
\text { units }\end{array}$ & $\begin{array}{c}\text { Number } \\
\text { of } \\
\text { samples }\end{array}$ & Mean & $\begin{array}{l}\text { Standard } \\
\text { deviation } \\
\text { (SD) }\end{array}$ & $\begin{array}{l}\text { MDL = } \\
3 \times S D\end{array}$ & $\begin{array}{l}\text { Lower } \\
\text { reporting } \\
\text { limit }\end{array}$ & $\begin{array}{l}\text { Upper } \\
\text { reporting } \\
\text { limit }\end{array}$ \\
\hline Ag 328.066 & axial & $\mu g / L$ & 30 & 0.01 & 0.71 & 2.14 & 5 & 10000 \\
\hline Ag 338.288 & axial & $\mu \mathrm{g} / \mathrm{L}$ & 30 & 1.0 & 0.9 & 2.8 & 5 & 10000 \\
\hline Al 396.151 & radial & $\mu \mathrm{g} / \mathrm{L}$ & 30 & -3 & 5 & 14 & 30 & 100000 \\
\hline Al 308.212 & radial & $\mu g / L$ & 30 & -3 & 5 & 15 & 30 & 100000 \\
\hline As 188.980 & radial & $\mu \mathrm{g} / \mathrm{L}$ & 30 & -2 & 6 & 17 & 50 & 10000 \\
\hline As 193.696 & radial & $\mu \mathrm{g} / \mathrm{L}$ & 30 & 9 & 7 & 21 & 50 & 10000 \\
\hline As 193.696 & axial & $\mu \mathrm{g} / \mathrm{L}$ & 30 & 2 & 2 & 6 & 50 & 10000 \\
\hline В 249.772 & radial & $\mu \mathrm{g} / \mathrm{L}$ & 30 & -0.7 & 0.2 & 0.7 & 5 & 10000 \\
\hline B 249.676 & radial & $\mu \mathrm{g} / \mathrm{L}$ & 30 & -0.2 & 0.7 & 2.1 & 5 & 10000 \\
\hline Ba 455.402 & radial & $\mu \mathrm{g} / \mathrm{L}$ & 30 & 0.8 & 0.2 & 0.5 & 1 & 10000 \\
\hline Ва 233.524 & radial & $\mu \mathrm{g} / \mathrm{L}$ & 30 & -0.2 & 0.2 & 0.7 & 1 & 10000 \\
\hline Be 313.104 & radial & $\mu g / L$ & 30 & -0.04 & 0.04 & 0.11 & 10 & 10000 \\
\hline Be 313.042 & radial & $\mu \mathrm{g} / \mathrm{L}$ & 30 & 0.02 & 0.03 & 0.10 & 10 & 10000 \\
\hline Ca 317.932 & radial & $\mathrm{mg} / \mathrm{L}$ & 30 & -0.291 & 0.002 & 0.006 & 0.1 & 1000 \\
\hline Ca 422.673 & radial & $\mathbf{m g} / \mathbf{L}$ & 30 & -0.210 & 0.005 & 0.014 & 0.1 & 1000 \\
\hline $\mathrm{Cd} 226.502$ & axial & $\mu \mathrm{g} / \mathrm{L}$ & 30 & 0.006 & 0.085 & 0.254 & 5 & 10000 \\
\hline Cd 214.434 & axial & $\mu g / L$ & 30 & 0.02 & 0.07 & 0.21 & 5 & 10000 \\
\hline Co 228.615 & axial & $\mu \mathrm{g} / \mathrm{L}$ & 30 & 0.2 & 0.1 & 0.3 & 10 & 10000 \\
\hline Co 230.785 & radial & $\mu \mathrm{g} / \mathrm{L}$ & 30 & 1.3 & 0.5 & 1.6 & 10 & 10000 \\
\hline Cr 205.560 & axial & $\mu \mathrm{g} / \mathrm{L}$ & 30 & -0.3 & 0.2 & 0.6 & 10 & 10000 \\
\hline Cr 267.711 & radial & $\mu \mathrm{g} / \mathbf{L}$ & 30 & -0.4 & 0.5 & 1.6 & 10 & 10000 \\
\hline $\mathrm{Cu} 324.754$ & radial & $\mu \mathrm{g} / \mathrm{L}$ & 30 & -1 & 2 & 7 & 10 & 10000 \\
\hline Cu 327.393 & axial & $\mu \mathrm{g} / \mathrm{L}$ & 30 & 4 & 1 & 3 & 10 & 10000 \\
\hline Fe 238.201 & radial & $\mu \mathrm{g} / \mathrm{L}$ & 30 & 0.2 & 0.3 & 0.9 & 20 & 100000 \\
\hline Fe 239.568 & axial & $\mu g / L$ & 30 & 3.5 & 0.1 & 0.4 & 20 & 100000 \\
\hline K 766.490 & radial & $\mathrm{mg} / \mathrm{L}$ & 30 & -0.02 & 0.05 & 0.14 & 0.5 & 1000 \\
\hline Li 670.784 & radial & $\mu \mathrm{g} / \mathrm{L}$ & 30 & -0.7 & 1.2 & 3.6 & 5 & 1000 \\
\hline Mg 285.212 & radial & $\mathrm{mg} / \mathrm{L}$ & 30 & -0.008 & 0.002 & 0.006 & 0.1 & 1000 \\
\hline Mg 279.076 & radial & $\mathrm{mg} / \mathrm{L}$ & 30 & -0.050 & 0.004 & 0.011 & 0.1 & 1000 \\
\hline Mn 257.607 & radial & $\mu g / L$ & 30 & 0.13 & 0.08 & 0.25 & 10 & 10000 \\
\hline Mn 293.305 & radial & $\mu \mathrm{g} / \mathrm{L}$ & 30 & 0.6 & 0.6 & 1.7 & 10 & 10000 \\
\hline Mo 202.032 & axial & $\mu \mathrm{g} / \mathrm{L}$ & 30 & 0.2 & 0.4 & 1.1 & 20 & 10000 \\
\hline Мo 203.846 & axial & $\mu g / L$ & 30 & 0.1 & 0.7 & 2.1 & 20 & 10000 \\
\hline Na 589.587 & radial & $\mathbf{m g} / \mathbf{L}$ & 30 & -0.31 & 0.02 & 0.06 & 0.1 & 1000 \\
\hline $\mathrm{Na} 330.237$ & radial & $\mathrm{mg} / \mathrm{L}$ & 30 & -0.4 & 0.1 & 0.4 & 1 & 1000 \\
\hline Ni 231.604 & radial & $\mu g / L$ & 30 & 0.5 & 1.2 & 3.7 & 10 & 10000 \\
\hline Ni 231.604 & axial & $\mu \mathrm{g} / \mathrm{L}$ & 30 & -0.1 & 0.4 & 1.3 & 10 & 10000 \\
\hline P 213.617 & radial & $\mathrm{mg} / \mathrm{L}$ & 30 & -0.006 & 0.006 & 0.017 & 0.5 & 10000 \\
\hline P 178.224 & radial & $\mathrm{mg} / \mathrm{L}$ & 30 & 0.15 & 0.09 & 0.26 & 0.5 & 10000 \\
\hline $\mathrm{Pb} 220.354$ & radial & $\mu \mathrm{g} / \mathrm{L}$ & 30 & -2 & 5 & 14 & 50 & 10000 \\
\hline Pb 220.354 & axial & $\mu g / L$ & 30 & 0.4 & 0.7 & 2.1 & 50 & 10000 \\
\hline$S^{1} 180.671$ & axial & $\mathrm{mg} / \mathrm{L}$ & 30 & 0.44 & 0.02 & 0.06 & 1 & 1000 \\
\hline$S^{1} 181.975$ & axial & $\mathrm{mg} / \mathrm{L}$ & 30 & -0.03 & 0.02 & 0.05 & 1 & 1000 \\
\hline
\end{tabular}


Table 5. Blanks analysis.-Continued

[SD, standard deviation; MDL, method detection limit; $\mu \mathrm{g} / \mathrm{L}$, micrograms per liter; $\mathrm{mg} / \mathrm{L}$, milligrams per liter; preferred lines are in bold]

\begin{tabular}{|c|c|c|c|c|c|c|c|c|}
\hline $\begin{array}{l}\text { Element and } \\
\text { wavelength }\end{array}$ & $\begin{array}{l}\text { Detection } \\
\text { view }\end{array}$ & $\begin{array}{c}\text { Calibration } \\
\text { units }\end{array}$ & $\begin{array}{c}\text { Number } \\
\text { of } \\
\text { samples }\end{array}$ & Mean & $\begin{array}{l}\text { Standard } \\
\text { deviation } \\
\text { (SD) }\end{array}$ & $\begin{array}{l}M D L= \\
3 \times S D\end{array}$ & $\begin{array}{l}\text { Lower } \\
\text { reporting } \\
\text { limit }\end{array}$ & $\begin{array}{l}\text { Upper } \\
\text { reporting } \\
\text { limit }\end{array}$ \\
\hline Sb 206.834 & axial & $\mu g / L$ & 30 & 14 & 1 & 4 & 50 & 10000 \\
\hline Sb 217.582 & radial & $\mu \mathrm{g} / \mathrm{L}$ & 30 & 18 & 14 & 41 & 50 & 10000 \\
\hline Si 251.609 & radial & $\mathrm{mg} / \mathrm{L}$ & 30 & 0.010 & 0.003 & 0.009 & 0.1 & 1000 \\
\hline Si 221.663 & radial & $\mathrm{mg} / \mathrm{L}$ & 30 & 0.023 & 0.004 & 0.013 & 0.1 & 1000 \\
\hline Sr 421.549 & radial & $\mu \mathrm{g} / \mathrm{L}$ & 30 & -0.35 & 0.06 & 0.18 & 1 & 10000 \\
\hline Sr 460.733 & radial & $\mu \mathrm{g} / \mathrm{L}$ & 30 & 7 & 9 & 26 & 50 & 10000 \\
\hline V 292.402 & axial & $\mu g / L$ & 30 & 0.8 & 0.4 & 1.3 & 10 & 10000 \\
\hline V 290.880 & radial & $\mu \mathrm{g} / \mathrm{L}$ & 30 & -3.3 & 0.2 & 0.7 & 10 & 10000 \\
\hline Zn 213.858 & axial & $\mu \mathrm{g} / \mathrm{L}$ & 30 & 4.7 & 0.1 & 0.4 & 20 & 10000 \\
\hline Zn 206.199 & axial & $\mu \mathrm{g} / \mathrm{L}$ & 30 & 1.75 & 0.08 & 0.24 & 20 & 10000 \\
\hline
\end{tabular}

${ }^{1} \mathrm{~S}$ is reported as sulfate $\left(\mathrm{SO}_{4}\right)$

Table 6 summarizes the interferences associated with the wavelength used in the method, the peak processing used for each wavelength, and the preferred wavelength for each element. The spectra obtained at each wavelength were processed either using peak height or MSF alogorithms. The MSF function is used in two different ways: (1) to change and remove the presence of interfences (examples include Be 313.104, Cd 226.502, S 180.6671), and (2) to minimize the background noise and improve detection limits.

Table 6. Interferences and peak processing algorithm.

[MSF, multicomponent spectral fitting]

\begin{tabular}{|c|c|c|c|c|}
\hline $\begin{array}{l}\text { Element and } \\
\text { wavelength }\end{array}$ & $\begin{array}{l}\text { Detection } \\
\text { view }\end{array}$ & $\begin{array}{l}\text { Interfering } \\
\text { elements }\end{array}$ & $\begin{array}{c}\text { Peak } \\
\text { processing }\end{array}$ & $\begin{array}{c}\text { Preferred } \\
\text { wavelength }\end{array}$ \\
\hline Ag 328.066 & axial & $\mathrm{Th}, \mathrm{Zr}, \mathrm{V}$ & peak area & preferred \\
\hline Ag 338.288 & axial & $\mathrm{Cr}, \mathrm{Th}$ & MSF & \\
\hline Al 396.151 & radial & $\mathrm{Mo}, \mathrm{Zr}$ & peak area & \\
\hline Al 308.212 & radial & Ce, Th, V & MSF & preferred \\
\hline As 188.980 & radial & $\mathrm{Cr}, \mathrm{Mo}$ & MSF & \\
\hline As 193.696 & radial & $\mathrm{V}$ & peak height & \\
\hline As 193.696 & axial & $\mathrm{V}$ & peak height & preferred \\
\hline B 249.772 & radial & $\mathrm{Fe}, \mathrm{Th}$ & MSF & \\
\hline В 249.676 & radial & $\mathrm{Fe}, \mathrm{Zr}$ & peak height & preferred \\
\hline $\mathrm{Ba} 455.402$ & radial & & peak height & preferred \\
\hline Ba 233.524 & radial & $\mathrm{V}$ & peak height & \\
\hline Be 313.104 & radial & $\mathrm{Ce}, \mathrm{Th}$ & MSF & preferred \\
\hline Be 313.042 & radial & V & MSF & \\
\hline Ca 317.932 & radial & Th & peak height & \\
\hline $\mathrm{Ca} 422.673$ & radial & $\mathrm{Sr}$ & peak height & preferred \\
\hline
\end{tabular}


Table 6. Interferences and peak processing algorithm.-Continued

[MSF, multicomponent spectral fitting]

\begin{tabular}{|c|c|c|c|c|}
\hline $\begin{array}{l}\text { Element and } \\
\text { wavelength }\end{array}$ & $\begin{array}{c}\text { Detection } \\
\text { view }\end{array}$ & $\begin{array}{l}\text { Interfering } \\
\text { elements }\end{array}$ & $\begin{array}{c}\text { Peak } \\
\text { processing }\end{array}$ & $\begin{array}{c}\text { Preferred } \\
\text { wavelength }\end{array}$ \\
\hline Cd 226.502 & axial & $\mathrm{Fe}$ & MSF & \\
\hline Cd 214.434 & axial & & MSF & preferred \\
\hline Co 228.615 & axial & & MSF & \\
\hline Co 230.785 & radial & Mo & peak height & preferred \\
\hline Cr 205.560 & axial & & peak area & \\
\hline Cr 267.711 & radial & & MSF & preferred \\
\hline $\mathrm{Cu} 324.754$ & radial & $\mathrm{Th}, \mathrm{Mg}$ & MSF & \\
\hline $\mathrm{Cu} 327.393$ & axial & Th & peak area & preferred \\
\hline $\mathrm{Fe} 238.201$ & radial & & peak height & \\
\hline Fe 239.568 & axial & Co & peak height & preferred \\
\hline K 766.490 & radial & & peak area & preferred \\
\hline Li 670.784 & radial & & peak area & preferred \\
\hline $\operatorname{Mg} 285.212$ & radial & & peak height & preferred \\
\hline Mg 279.076 & radial & & peak height & \\
\hline Mn 257.607 & radial & & peak height & preferred \\
\hline Mn 293.305 & radial & $\mathrm{V}, \mathrm{Th}$ & MSF & \\
\hline Mo 202.032 & axial & & peak height & \\
\hline Mo 203.846 & axial & & peak height & preferred \\
\hline Na 589.587 & radial & & peak height & preferred \\
\hline $\mathrm{Na} 330.237$ & radial & $\mathrm{Zn}, \mathrm{Zr}$ & peak height & \\
\hline Ni 231.604 & radial & & peak area & preferred \\
\hline Ni 231.604 & axial & & peak area & \\
\hline P 213.617 & radial & $\mathrm{Cu}$ & MSF & preferred \\
\hline P 178.224 & radial & & peak height & \\
\hline $\mathrm{Pb} 220.354$ & radial & & peak area & preferred \\
\hline $\mathrm{Pb} 220.354$ & axial & & peak area & \\
\hline$S^{1} 180.671$ & axial & $\mathrm{Ca}$ & MSF & \\
\hline$S^{1} 181.975$ & axial & & peak area & preferred \\
\hline Sb 206.834 & axial & $\mathrm{Cr}$ & peak area & preferred \\
\hline Sb 217.582 & radial & & peak area & \\
\hline Si 251.609 & radial & & peak height & preferred \\
\hline Si 221.663 & radial & & peak height & \\
\hline Sr 421.549 & radial & & peak height & preferred \\
\hline Sr 460.733 & radial & & MSF & \\
\hline V 292.402 & axial & & MSF & preferred \\
\hline V 290.880 & radial & & MSF & \\
\hline Zn 213.858 & axial & $\mathrm{Ca}$ & peak height & \\
\hline Zn 206.199 & axial & & peak height & preferred \\
\hline
\end{tabular}

${ }^{1} \mathrm{~S}$ is reported as sulfate $\left(\mathrm{SO}_{4}\right)$ 


\section{Method Performance-Analyses of CRMs and Duplicate Samples}

Table 7 summarizes the results obtained for six standard reference materials analyzed by this method: T131, T135, T143, T175, M158, and PPREE. These samples, in addition to ICV samples discussed in the ICP-OES analyses section, are used to check the methods performance and for QC/QA purposes. Unknown samples range from pristinely clean natural waters to mine waste waters and various leachates, and they vary largely in the concentrations of their trace and major elements. The six CRMs shown in this report represent trace and major elements in natural waters collected at various locations in Colorado in which the trace and major constituents are adjusted (USGS Standard Reference Sample Project, http://bqs.usgs.gov/srs/). These samples represent trace and major elements in natural waters, and for many elements, the levels are near the detection limits and are useful for evaluating accuracy at low concentrations. The accepted or most probable value (MPV) for the USGS reference waters is determined via multi-laboratory round-robin analysis. The PPREE sample is a rare-earth element CRM developed using mine water collected in western San Juan Mountains, Colo. (Verplank, 2001). This sample is elevated in $\mathrm{Al}, \mathrm{Ca}, \mathrm{Fe}, \mathrm{Mg}, \mathrm{Mn}, \mathrm{Sr}$, and rare-earth elements. Many of the interferences shown in table 6 are caused by these elements, and the obtained concentrations are within \pm 20 percent of the accepted value for this CRM. Table 8 shows the results for 71 duplicate pairs, selected randomly from a variety of geological water samples, to demonstrate the reproducibility of the method.

Table 7. Standard reference material analysis.

[n, number; SD, standard deviation; \%, percent; $\mu \mathrm{g} / \mathrm{L}$, micrograms per liter; <, less than; N/A, not applicable; mg/L, milligrams per liter]

\begin{tabular}{|c|c|c|c|c|c|c|c|}
\hline \multicolumn{2}{|c|}{ Reference material } & \multirow[t]{2}{*}{ Description } & \multirow[t]{2}{*}{$\mathrm{n}$} & \multirow{2}{*}{$\begin{array}{c}\text { Average } \\
\text { determined } \\
\text { value }\end{array}$} & \multirow[t]{2}{*}{ SD } & \multirow[t]{2}{*}{$\begin{array}{l}\text { Accepted } \\
\text { value }\end{array}$} & \multirow[t]{2}{*}{$\%$ Recovery } \\
\hline Silver, Ag & $\mu \mathrm{g} / \mathrm{L}$ & & & & & & \\
\hline $\mathrm{T} 131$ & & trace constituents & 20 & $<5$ & & 1.26 & \\
\hline $\mathrm{T} 135$ & & trace constituents & 15 & 12 & 1 & 9.81 & 124 \\
\hline M158 & & major constituents & 15 & $<5$ & & N/A & \\
\hline $\mathrm{T} 175$ & & trace constituents & 15 & $<5$ & & 1.85 & \\
\hline $\mathrm{T} 143$ & & trace constituents & 15 & 23 & 1 & 19.8 & 118 \\
\hline PPREE & & trace constituents & 15 & $<5$ & & N/A & \\
\hline \multicolumn{8}{|c|}{ Aluminum, $\mathrm{Al} \quad \mu \mathrm{g} / \mathrm{L}$} \\
\hline $\mathrm{T} 131$ & & trace constituents & 20 & 127 & 5 & 132 & 96 \\
\hline $\mathrm{T} 135$ & & trace constituents & 15 & $<30$ & & 10.5 & \\
\hline M158 & & major constituents & 15 & $<30$ & & $\mathrm{~N} / \mathrm{A}$ & \\
\hline $\mathrm{T} 175$ & & trace constituents & 5 & 45 & 10 & 52.0 & 87 \\
\hline $\mathrm{T} 143$ & & trace constituents & 15 & $<30$ & 3 & 22.1 & 116 \\
\hline PPREE & & trace constituents & 15 & 11400 & 120 & 11500 & 99 \\
\hline \multicolumn{8}{|c|}{ Arsenic, As $\quad \mu \mathrm{g} / \mathrm{L}$} \\
\hline $\mathrm{T} 131$ & & trace constituents & 20 & 58 & 3 & 56.6 & 103 \\
\hline $\mathrm{T} 135$ & & trace constituents & 15 & $<50$ & & 10.0 & \\
\hline M158 & & major constituents & 15 & $<50$ & & $\mathrm{~N} / \mathrm{A}$ & \\
\hline $\mathrm{T} 175$ & & trace constituents & 15 & $<50$ & & 7.38 & \\
\hline $\mathrm{T} 143$ & & trace constituents & 15 & $<50$ & & 15.2 & \\
\hline PPREE & & trace constituents & 15 & $<50$ & & 1.8 & \\
\hline
\end{tabular}


Table 7. Standard reference material analysis. - Continued

[n, number; SD, standard deviation; \%, percent; $\mu \mathrm{g} / \mathrm{L}$, micrograms per liter; <, less than; N/A, not applicable; mg/L, milligrams per liter]

\begin{tabular}{|c|c|c|c|c|c|c|c|}
\hline \multicolumn{2}{|c|}{ Reference material } & \multirow[t]{2}{*}{ Description } & \multirow[t]{2}{*}{$\mathrm{n}$} & \multirow{2}{*}{$\begin{array}{c}\text { Average } \\
\text { determined } \\
\text { value }\end{array}$} & \multirow[t]{2}{*}{ SD } & \multirow[t]{2}{*}{$\begin{array}{l}\text { Accepted } \\
\text { value }\end{array}$} & \multirow[t]{2}{*}{$\%$ Recovery } \\
\hline Boron, B & $\mu \mathrm{g} / \mathrm{L}$ & & & & & & \\
\hline $\mathrm{T} 131$ & & trace constituents & 20 & 143 & 11 & 141 & 102 \\
\hline T135 & & trace constituents & 15 & 10 & 1 & 13.1 & 77 \\
\hline M158 & & major constituents & 15 & 23 & 0 & 23.4 & 97 \\
\hline $\mathrm{T} 175$ & & trace constituents & 15 & 48 & 1 & 48.3 & 99 \\
\hline $\mathrm{T} 143$ & & trace constituents & 15 & 35 & 1 & 35.0 & 100 \\
\hline PPREE & & trace constituents & 15 & $<5$ & & N/A & \\
\hline Barium, $\mathrm{Ba}$ & $\mu \mathrm{g} / \mathrm{L}$ & & & & & & \\
\hline $\mathrm{T} 131$ & & trace constituents & 20 & 526 & 19.8 & 507 & 104 \\
\hline $\mathrm{T} 135$ & & trace constituents & 15 & 71 & 2.0 & 67.8 & 105 \\
\hline M158 & & major constituents & 15 & 25 & 0.4 & N/A & \\
\hline $\mathrm{T} 175$ & & trace constituents & 15 & 21 & 0.6 & 18.0 & 115 \\
\hline $\mathrm{T} 143$ & & trace constituents & 15 & 91 & 2.2 & 81.9 & 111 \\
\hline PPREE & & trace constituents & 15 & 9 & 0.3 & 7.1 & 126 \\
\hline Berilium, Be & $\mu \mathrm{g} / \mathrm{L}$ & & & & & & \\
\hline $\mathrm{T} 131$ & & trace constituents & 20 & 12 & 0.4 & 12.2 & 101 \\
\hline $\mathrm{T} 135$ & & trace constituents & 15 & 59 & 0.6 & 59.0 & 100 \\
\hline M158 & & major constituents & 15 & $<10$ & & N/A & \\
\hline $\mathrm{T} 175$ & & trace constituents & 15 & $<10$ & & 2.92 & \\
\hline $\mathrm{T} 143$ & & trace constituents & 15 & $<10$ & & 8.50 & \\
\hline PPREE & & trace constituents & 15 & $<10$ & & 2.5 & \\
\hline Calcium, $\mathrm{Ca}$ & $\mathrm{mg} / \mathrm{L}$ & & & & & & \\
\hline $\mathrm{T} 131$ & & trace constituents & 20 & 30 & 1 & 30.6 & 99 \\
\hline $\mathrm{T} 135$ & & trace constituents & 15 & 11 & 0 & 10.4 & 103 \\
\hline M158 & & major constituents & 15 & 40 & 1 & 38.1 & 106 \\
\hline $\mathrm{T} 175$ & & trace constituents & 15 & 9 & 0 & 8.76 & 106 \\
\hline $\mathrm{T} 143$ & & trace constituents & 15 & 57 & 2 & 53.7 & 105 \\
\hline PPREE & & trace constituents & 15 & 411 & 8 & 348 & 118 \\
\hline Cadmium, $\mathrm{Cd}$ & $\mu \mathrm{g} / \mathrm{L}$ & & & & & & \\
\hline $\mathrm{T} 131$ & & trace constituents & 20 & 6 & 0.3 & 6.12 & 101 \\
\hline $\mathrm{T} 135$ & & trace constituents & 15 & 52 & 1.0 & 50.5 & 103 \\
\hline M158 & & major constituents & 15 & $<5$ & & N/A & \\
\hline $\mathrm{T} 175$ & & trace constituents & 15 & 9 & 0.3 & 8.20 & 111 \\
\hline $\mathrm{T} 143$ & & trace constituents & 15 & 20 & 0.4 & 19.1 & 107 \\
\hline PPREE & & trace constituents & 15 & $<5$ & & 0.4 & \\
\hline
\end{tabular}


Table 7. Standard reference material analysis. - Continued

[n, number; SD, standard deviation; \%, percent; $\mu \mathrm{g} / \mathrm{L}$, micrograms per liter; <, less than; N/A, not applicable; mg/L, milligrams per liter]

\begin{tabular}{|c|c|c|c|c|c|c|c|}
\hline \multicolumn{2}{|c|}{ Reference material } & \multirow[t]{2}{*}{ Description } & \multirow[t]{2}{*}{$\mathrm{n}$} & \multirow{2}{*}{$\begin{array}{l}\text { Average } \\
\text { determined } \\
\text { value }\end{array}$} & \multirow[t]{2}{*}{ SD } & \multirow[t]{2}{*}{$\begin{array}{l}\text { Accepted } \\
\text { value }\end{array}$} & \multirow[t]{2}{*}{$\%$ Recovery } \\
\hline Cobalt, Co & $\mu \mathrm{g} / \mathrm{L}$ & & & & & & \\
\hline $\mathrm{T} 131$ & & trace constituents & 20 & 25 & 0.7 & 24.6 & 100 \\
\hline T135 & & trace constituents & 15 & 42 & 1.3 & 40.0 & 104 \\
\hline M158 & & major constituents & 15 & $<10$ & & $\mathrm{~N} / \mathrm{A}$ & \\
\hline $\mathrm{T} 175$ & & trace constituents & 15 & $<10$ & & 7.4 & \\
\hline $\mathrm{T} 143$ & & trace constituents & 15 & 16 & 0.5 & 17.0 & 96 \\
\hline PPREE & & trace constituents & 15 & 111 & 1.6 & 98 & 114 \\
\hline Chromium, $\mathrm{Cr}$ & $\mu \mathrm{g} / \mathrm{L}$ & & & & & & \\
\hline $\mathrm{T} 131$ & & trace constituents & 20 & 19 & 0.3 & 18.6 & 102 \\
\hline $\mathrm{T} 135$ & & trace constituents & 15 & 81 & 1.6 & 79.0 & 103 \\
\hline M158 & & major constituents & 15 & $<10$ & & N/A & \\
\hline $\mathrm{T} 175$ & & trace constituents & 15 & $<10$ & & 1.9 & \\
\hline T143 & & trace constituents & 15 & 39 & 0.5 & 37.0 & 105 \\
\hline PPREE & & trace constituents & 15 & & & N/A & \\
\hline Copper, $\mathrm{Cu}$ & $\mu \mathrm{g} / \mathrm{L}$ & & & & & & \\
\hline $\mathrm{T} 131$ & & trace constituents & 20 & 20 & 1.2 & 20.2 & 98 \\
\hline $\mathrm{T} 135$ & & trace constituents & 15 & 63 & 1.0 & 62.0 & 102 \\
\hline M158 & & major constituents & 15 & $<10$ & & N/A & \\
\hline $\mathrm{T} 175$ & & trace constituents & 15 & $<10$ & & 1.85 & \\
\hline $\mathrm{T} 143$ & & trace constituents & 15 & 21 & 0.7 & 22.3 & 95 \\
\hline PPREE & & trace constituents & 15 & $<10$ & & 0.40 & \\
\hline Iron, Fe & $\mu \mathrm{g} / \mathrm{L}$ & & & & & & \\
\hline $\mathrm{T} 131$ & & trace constituents & 20 & 85 & 3 & 91 & 94 \\
\hline $\mathrm{T} 135$ & & trace constituents & 15 & 212 & 4 & 228 & 93 \\
\hline M158 & & major constituents & 15 & $<20$ & & N/A & \\
\hline $\mathrm{T} 175$ & & trace constituents & 15 & 34 & 1 & 40 & 87 \\
\hline $\mathrm{T} 143$ & & trace constituents & 15 & 210 & 3 & 222 & 95 \\
\hline PPREE & & trace constituents & 15 & 60600 & 666 & 68300 & 89 \\
\hline Potassium, $\mathrm{K}$ & $\mathrm{mg} / \mathrm{L}$ & & & & & & \\
\hline $\mathrm{T} 131$ & & trace constituents & 20 & 2.21 & 0.09 & 2.39 & 92 \\
\hline $\mathrm{T} 135$ & & trace constituents & 15 & 0.85 & 0.08 & 0.96 & 88 \\
\hline M158 & & major constituents & 15 & 1.78 & 0.04 & 1.71 & 104 \\
\hline $\mathrm{T} 175$ & & trace constituents & 15 & 3.62 & 0.08 & 3.83 & 95 \\
\hline $\mathrm{T} 143$ & & trace constituents & 15 & 2.50 & 0.07 & 2.50 & 100 \\
\hline PPREE & & trace constituents & 15 & 0.96 & 0.09 & 0.94 & 102 \\
\hline
\end{tabular}


Table 7. Standard reference material analysis. - Continued

[n, number; SD, standard deviation; \%, percent; $\mu \mathrm{g} / \mathrm{L}$, micrograms per liter; <, less than; N/A, not applicable; mg/L, milligrams per liter]

\begin{tabular}{|c|c|c|c|c|c|c|c|}
\hline \multicolumn{2}{|c|}{ Reference material } & \multirow[t]{2}{*}{ Description } & \multirow[t]{2}{*}{$\mathrm{n}$} & \multirow{2}{*}{$\begin{array}{l}\text { Average } \\
\text { determined } \\
\text { value }\end{array}$} & \multirow[t]{2}{*}{ SD } & \multirow{2}{*}{$\begin{array}{l}\text { Accepted } \\
\text { value }\end{array}$} & \multirow[t]{2}{*}{$\%$ Recovery } \\
\hline Lithium, Li & $\mu \mathrm{g} / \mathrm{L}$ & & & & & & \\
\hline $\mathrm{T} 131$ & & trace constituents & 20 & 18 & 1.5 & 17.00 & 103 \\
\hline $\mathrm{T} 135$ & & trace constituents & 15 & 75 & 1.9 & 73.7 & 102 \\
\hline M158 & & major constituents & 15 & $<5$ & & N/A & \\
\hline $\mathrm{T} 175$ & & trace constituents & 15 & 6 & 0.5 & 3.20 & 181 \\
\hline $\mathrm{T} 143$ & & trace constituents & 15 & 19 & 1.1 & 18.00 & 103 \\
\hline PPREE & & trace constituents & 15 & 8 & 1.7 & 6.0 & 130 \\
\hline \multicolumn{8}{|c|}{ Magnesium, $\mathrm{Mg} \quad \mathrm{mg} / \mathrm{L}$} \\
\hline $\mathrm{T} 131$ & & trace constituents & 20 & 7.27 & 0.16 & 8.00 & 91 \\
\hline T135 & & trace constituents & 15 & 1.83 & 0.05 & 2.00 & 92 \\
\hline M158 & & major constituents & 15 & 10.9 & 0.09 & 11.8 & 93 \\
\hline $\mathrm{T} 175$ & & trace constituents & 15 & 1.91 & 0.06 & 2.03 & 94 \\
\hline $\mathrm{T} 143$ & & trace constituents & 15 & 9.73 & 0.11 & 10.4 & 94 \\
\hline PPREE & & trace constituents & 15 & 34.0 & 0.40 & 34.6 & 98 \\
\hline Manganese, Mn & $\mu \mathrm{g} / \mathrm{L}$ & & & & & & \\
\hline $\mathrm{T} 131$ & & trace constituents & 20 & 39 & 1.4 & 37.8 & 103 \\
\hline $\mathrm{T} 135$ & & trace constituents & 15 & 452 & 5.8 & 423 & 107 \\
\hline M158 & & major constituents & 15 & $<10$ & & N/A & \\
\hline $\mathrm{T} 175$ & & trace constituents & 15 & 55 & 1.4 & 49.4 & 112 \\
\hline $\mathrm{T} 143$ & & trace constituents & 15 & 20 & 0.5 & 18.2 & 109 \\
\hline PPREE & & trace constituents & 15 & 5870 & 36.2 & 5300 & 111 \\
\hline Molybdenum, & $\mu \mathrm{g} / \mathrm{L}$ & & & & & & \\
\hline $\mathrm{T} 131$ & & trace constituents & 20 & 110 & 3 & 112 & 98 \\
\hline $\mathrm{T} 135$ & & trace constituents & 15 & 56 & 2 & 63 & 89 \\
\hline M158 & & major constituents & 15 & $<20$ & & $\mathrm{~N} / \mathrm{A}$ & \\
\hline $\mathrm{T} 175$ & & trace constituents & 15 & $<20$ & & 2 & \\
\hline $\mathrm{T} 143$ & & trace constituents & 15 & 31 & 0.9 & 36.1 & 85 \\
\hline PPREE & & trace constituents & 15 & $<20$ & & N/A & \\
\hline Sodium, $\mathrm{Na}$ & $\mathrm{mg} / \mathrm{L}$ & & & & & & \\
\hline $\mathrm{T} 131$ & & trace constituents & 20 & 21 & 0.9 & 21.4 & 98 \\
\hline $\mathrm{T} 135$ & & trace constituents & 15 & 31 & 1.3 & 30.8 & 100 \\
\hline M158 & & major constituents & 15 & 73 & 2.0 & 71.7 & 102 \\
\hline $\mathrm{T} 175$ & & trace constituents & 15 & 9 & 0.2 & 8.6 & 100 \\
\hline $\mathrm{T} 143$ & & trace constituents & 15 & 34 & 1.2 & 34.0 & 101 \\
\hline PPREE & & trace constituents & 15 & 9 & 0.1 & 8.1 & 107 \\
\hline
\end{tabular}


Table 7. Standard reference material analysis. - Continued

[n, number; SD, standard deviation; \%, percent; $\mu \mathrm{g} / \mathrm{L}$, micrograms per liter; <, less than; N/A, not applicable; mg/L, milligrams per liter]

\begin{tabular}{|c|c|c|c|c|c|c|c|}
\hline \multicolumn{2}{|c|}{ Reference material } & \multirow[t]{2}{*}{ Description } & \multirow[t]{2}{*}{$\mathrm{n}$} & \multirow{2}{*}{$\begin{array}{c}\text { Average } \\
\text { determined } \\
\text { value }\end{array}$} & \multirow[t]{2}{*}{ SD } & \multirow[t]{2}{*}{$\begin{array}{l}\text { Accepted } \\
\text { value }\end{array}$} & \multirow[t]{2}{*}{$\%$ Recovery } \\
\hline Nickel, Ni & $\mu \mathrm{g} / \mathrm{L}$ & & & & & & \\
\hline $\mathrm{T} 131$ & & trace constituents & 20 & 64 & 2.6 & 56.3 & 113 \\
\hline $\mathrm{T} 135$ & & trace constituents & 15 & 73 & 2.1 & 65.6 & 112 \\
\hline M158 & & major constituents & 15 & $<10$ & & N/A & \\
\hline $\mathrm{T} 175$ & & trace constituents & 15 & $<10$ & & 3.2 & \\
\hline $\mathrm{T} 143$ & & trace constituents & 15 & 81 & 2.0 & 71.0 & 114 \\
\hline \multicolumn{8}{|c|}{ Phosphorus, $\mathrm{P} \quad \mathrm{mg} / \mathrm{L}$} \\
\hline $\mathrm{T} 131$ & & trace constituents & 20 & $<0.5$ & & N/A & \\
\hline $\mathrm{T} 135$ & & trace constituents & 15 & $<0.5$ & & N/A & \\
\hline M158 & & major constituents & 15 & $<0.5$ & & 0.06 & \\
\hline $\mathrm{T} 175$ & & trace constituents & 15 & $<0.5$ & & N/A & \\
\hline $\mathrm{T} 143$ & & trace constituents & 15 & $<0.5$ & & N/A & \\
\hline PPREE & & trace constituents & 15 & $<0.5$ & & 0.18 & \\
\hline Lead, $\mathrm{Pb}$ & $\mu \mathrm{g} / \mathrm{L}$ & & & & & & \\
\hline T131 & & trace constituents & 20 & $<50$ & & 18.1 & \\
\hline $\mathrm{T} 135$ & & trace constituents & 15 & 105 & 2.3 & 103 & 102 \\
\hline M158 & & major constituents & 15 & $<50$ & & N/A & \\
\hline $\mathrm{T} 175$ & & trace constituents & 15 & $<50$ & & 3.0 & \\
\hline $\mathrm{T} 143$ & & trace constituents & 15 & 92 & 1.5 & 83.4 & 110 \\
\hline PPREE & & trace constituents & 15 & $<50$ & & 0.1 & \\
\hline Antimony, $\mathrm{Sb}$ & $\mu \mathrm{g} / \mathrm{L}$ & & & & & & \\
\hline $\mathrm{T} 131$ & & trace constituents & 20 & 52 & 6 & 56 & 93 \\
\hline $\mathrm{T} 135$ & & trace constituents & 15 & 58 & 2 & 76 & 76 \\
\hline M158 & & major constituents & 15 & $<50$ & & N/A & \\
\hline $\mathrm{T} 175$ & & trace constituents & 15 & $<50$ & & 2 & \\
\hline $\mathrm{T} 143$ & & trace constituents & 15 & $<50$ & & 16.6 & \\
\hline PPREE & & trace constituents & 15 & $<50$ & & N/A & \\
\hline Silica, $\mathrm{SiO}_{2}$ & $\mathrm{mg} / \mathrm{L}$ & & & & & & \\
\hline $\mathrm{T} 131$ & & trace constituents & 20 & 5.8 & 0.2 & 5.81 & 100 \\
\hline $\mathrm{T} 135$ & & trace constituents & 15 & 4.1 & 0.1 & 4.28 & 96 \\
\hline M158 & & major constituents & 15 & 14.6 & 0.1 & 15.0 & 98 \\
\hline $\mathrm{T} 175$ & & trace constituents & 15 & 5.3 & 0.1 & 5.60 & 95 \\
\hline $\mathrm{T} 143$ & & trace constituents & 15 & 22.5 & 0.4 & 23.4 & 96 \\
\hline PPREE & & trace constituents & 15 & 29.4 & 0.3 & 27.8 & 106 \\
\hline Sulfate, $\mathrm{SO}_{4}$ & $\mathrm{mg} / \mathrm{L}$ & & & & & & \\
\hline $\mathrm{T} 131$ & & trace constituents & 20 & $<1$ & & $\mathrm{~N} / \mathrm{A}$ & \\
\hline $\mathrm{T} 135$ & & trace constituents & 15 & 6 & 0.1 & N/A & \\
\hline M158 & & major constituents & 15 & 115 & 1.3 & 105 & 110 \\
\hline $\mathrm{T} 175$ & & trace constituents & 15 & 14 & 0.3 & N/A & \\
\hline $\mathrm{T} 143$ & & trace constituents & 15 & 23 & 0.4 & N/A & \\
\hline PPREE & & trace constituents & 15 & 1410 & 89 & 1210 & 116 \\
\hline
\end{tabular}


Table 7. Standard reference material analysis. - Continued

[n, number; SD, standard deviation; \%, percent; $\mu \mathrm{g} / \mathrm{L}$, micrograms per liter; <, less than; N/A, not applicable; mg/L, milligrams per liter]

\begin{tabular}{|c|c|c|c|c|c|c|c|}
\hline \multicolumn{2}{|c|}{ Reference material } & \multirow[t]{2}{*}{ Description } & \multirow[t]{2}{*}{$\mathrm{n}$} & \multirow{2}{*}{$\begin{array}{c}\text { Average } \\
\text { determined } \\
\text { value }\end{array}$} & \multirow[t]{2}{*}{ SD } & \multirow[t]{2}{*}{$\begin{array}{l}\text { Accepted } \\
\text { value }\end{array}$} & \multirow[t]{2}{*}{$\%$ Recovery } \\
\hline Strontium, Sr & $\mu \mathrm{g} / \mathrm{L}$ & & & & & & \\
\hline $\mathrm{T} 131$ & & trace constituents & 20 & 315 & 15 & 295 & 107 \\
\hline $\mathrm{T} 135$ & & trace constituents & 15 & 52 & 1 & 46.0 & 112 \\
\hline M158 & & major constituents & 15 & 69 & 2 & 63.6 & 109 \\
\hline $\mathrm{T} 175$ & & trace constituents & 15 & 69 & 2 & 63.6 & 109 \\
\hline $\mathrm{T} 143$ & & trace constituents & 15 & 344 & 12 & 306 & 113 \\
\hline PPREE & & trace constituents & 15 & 3100 & 38 & 2680 & 116 \\
\hline Vanadium, V & $\mu \mathrm{g} / \mathrm{L}$ & & & & & & \\
\hline $\mathrm{T} 131$ & & trace constituents & 20 & 33 & 2 & 34 & 97 \\
\hline $\mathrm{T} 135$ & & trace constituents & 15 & 52 & 1 & 53 & 98 \\
\hline M158 & & major constituents & 15 & 11.1 & 0.5 & 11.3 & 99 \\
\hline $\mathrm{T} 175$ & & trace constituents & 15 & $<10$ & & N/A & \\
\hline $\mathrm{T} 143$ & & trace constituents & 15 & 29.1 & 0.9 & 30.0 & 97 \\
\hline PPREE & & trace constituents & 15 & $<10$ & & 3 & \\
\hline Zinc, $\mathrm{Zn}$ & $\mu \mathrm{g} / \mathrm{L}$ & & & & & & \\
\hline $\mathrm{T} 131$ & & trace constituents & 20 & 68 & 2.5 & 72 & 94 \\
\hline $\mathrm{T} 135$ & & trace constituents & 15 & 45 & 0.9 & 48 & 93 \\
\hline M158 & & major constituents & 15 & $<20$ & & N/A & \\
\hline $\mathrm{T} 175$ & & trace constituents & 15 & 68 & 1.4 & 72 & 94 \\
\hline $\mathrm{T} 143$ & & trace constituents & 15 & $<20$ & & 20 & \\
\hline PPREE & & trace constituents & 15 & 562 & 33 & 490 & 115 \\
\hline
\end{tabular}


Table 8. Duplicate analysis, based on the analyses of 71 duplicate pairs.

$[\%$, percent; RSD, relative standard deviation; $\mu \mathrm{g} / \mathrm{L}$, micrograms per liter; $\mathrm{mg} / \mathrm{L}$, milligrams per liter; MDL, method detection limit ]

\begin{tabular}{|c|c|c|c|c|c|c|c|c|}
\hline Element & $\begin{array}{l}\text { Concentration } \\
\text { units }\end{array}$ & Mean & $\begin{array}{l}\text { Standard } \\
\text { deviation }\end{array}$ & $\%$ RSD & Minimum & Maximum & $\begin{array}{c}\text { Maximum \% } \\
\text { difference } \\
\text { between } \\
\text { duplicates }\end{array}$ & $\begin{array}{l}\text { Number of } \\
\text { analysis higher } \\
\text { than MDL }\end{array}$ \\
\hline $\mathrm{Ag}$ & $\mu \mathrm{g} / \mathrm{L}$ & 9 & 2 & 24 & 5 & 18 & $18 \%$ & 22 \\
\hline $\mathrm{Al}$ & $\mu \mathrm{g} / \mathrm{L}$ & 12900 & 1900 & 15 & 20 & 174000 & $19 \%$ & 118 \\
\hline As & $\mu \mathrm{g} / \mathrm{L}$ & 1210 & 15 & 1 & 50 & 17300 & $14 \%$ & 58 \\
\hline B & $\mu \mathrm{g} / \mathrm{L}$ & 315 & 13 & 4 & 5 & 5290 & $17 \%$ & 78 \\
\hline $\mathrm{Ba}$ & $\mu \mathrm{g} / \mathrm{L}$ & 137 & 75 & 55 & 4 & 776 & $18 \%$ & 132 \\
\hline $\mathrm{Be}$ & $\mu \mathrm{g} / \mathrm{L}$ & $<10$ & & & & & $0 \%$ & 0 \\
\hline $\mathrm{Ca}$ & $\mathrm{mg} / \mathrm{L}$ & 38.8 & 5 & 12 & 0.5 & 469 & $13 \%$ & 134 \\
\hline $\mathrm{Cd}$ & $\mu \mathrm{g} / \mathrm{L}$ & 10 & 1 & 14 & 5 & 18 & $13 \%$ & 38 \\
\hline Co & $\mu \mathrm{g} / \mathrm{L}$ & 55 & 2 & 3 & 11 & 224 & $13 \%$ & 58 \\
\hline $\mathrm{Cr}$ & $\mu \mathrm{g} / \mathrm{L}$ & 45 & 1 & 2 & 10 & 111 & $6 \%$ & 34 \\
\hline $\mathrm{Cu}$ & $\mu \mathrm{g} / \mathrm{L}$ & 488 & 10 & 2 & 11 & 8420 & $17 \%$ & 64 \\
\hline $\mathrm{Fe}$ & $\mu \mathrm{g} / \mathrm{L}$ & 43700 & 700 & 2 & 21 & 626000 & $12 \%$ & 114 \\
\hline K & $\mathrm{mg} / \mathrm{L}$ & 6.8 & 2.5 & 37 & 0.1 & 39.2 & $13 \%$ & 130 \\
\hline $\mathrm{Li}$ & $\mu \mathrm{g} / \mathrm{L}$ & 36 & 7 & 21 & 5 & 213 & $16 \%$ & 104 \\
\hline $\mathrm{Mg}$ & $\mathrm{mg} / \mathrm{L}$ & 14.7 & 0.4 & 2 & 0.1 & 130 & $8 \%$ & 130 \\
\hline $\mathrm{Mn}$ & $\mu \mathrm{g} / \mathrm{L}$ & 1270 & 180 & 14 & 11 & 7630 & $14 \%$ & 106 \\
\hline Mo & $\mu \mathrm{g} / \mathrm{L}$ & 129 & 4 & 3 & 22 & 878 & $13 \%$ & 26 \\
\hline $\mathrm{Na}$ & $\mathrm{mg} / \mathrm{L}$ & 115 & 8.0 & 7 & 0.2 & 1950 & $16 \%$ & 136 \\
\hline $\mathrm{Ni}$ & $\mu \mathrm{g} / \mathrm{L}$ & 184 & 4 & 2 & 11 & 3250 & $11 \%$ & 70 \\
\hline $\mathrm{P}$ & $\mathrm{mg} / \mathrm{L}$ & 1.6 & 0.0 & 2 & 0.6 & 6.2 & $10 \%$ & 48 \\
\hline $\mathrm{Pb}$ & $\mu \mathrm{g} / \mathrm{L}$ & 96 & 7 & 7 & 81 & 110 & $14 \%$ & 10 \\
\hline $\mathrm{Sb}$ & $\mu \mathrm{g} / \mathrm{L}$ & 120 & 1 & 1 & 76 & 220 & $3 \%$ & 8 \\
\hline $\mathrm{SiO}_{2}$ & $\mathrm{mg} / \mathrm{L}$ & 17.0 & 1.8 & 10 & 0.3 & 83.0 & $12 \%$ & 100 \\
\hline $\mathrm{SO}_{4}$ & $\mathrm{mg} / \mathrm{L}$ & 177 & 3 & 2 & 2 & 2240 & $13 \%$ & 114 \\
\hline $\mathrm{Sr}$ & $\mu \mathrm{g} / \mathrm{L}$ & 257 & 27 & 11 & 1 & 2720 & $14 \%$ & 138 \\
\hline $\mathrm{V}$ & $\mu \mathrm{g} / \mathrm{L}$ & 106 & 9 & 8 & 13 & 311 & $9 \%$ & 50 \\
\hline $\mathrm{Zn}$ & $\mu \mathrm{g} / \mathrm{L}$ & 226 & 5 & 2 & 25 & 1220 & $13 \%$ & 72 \\
\hline
\end{tabular}

\section{References}

Boss, C.B., and Fredeen, K.J., 2004, Concepts, instrumentation and techniques in inductively-coupled plasma optical emission spectroscopy, 3rd Edition: Shelton, Conn., PerkinElmer, ID\#005446B, p. 4-4-4-24.

Farrar, J.W., Long, H.,K., 1997, Report on the U.S. Geological Survey's evaluation program for standard reference samples distributed in September 1996: T-143 (trace constituents), T-145 (trace constituents), M-140 (major constituents), N-51 (nutrient constituents), N-52 (nutrient constituents), P-27 (low ionic strength constituents), and Hg-23 (mercury); U.S. Geological Survey Open-File Report 97-20, 145 p. 
Ivaldi, J.C., and Barnard, T.W., Spectrochimica Acta Part B: Atomic Spectroscopy, v. 48, no. 10, August 1993, p. 1265-1273.

Long, H.K., and Farrar, J.W., 1995a, Report on the U.S. Geological Survey's evaluation program for standard reference samples distributed in October 1994-T-131 (trace constituents), T-133 (trace constituents), M-132 (major constituents), N-43 (nutrients), N-44 (nutrients), P-23 (low ionic strength) and Hg-19 (mercury): U.S. Geological Survey Open-File Report 95-117, 139 p.

Long, H.K., and Farrar, J.W., 1995b, Report on the U.S. Geological Survey's evaluation program for standard reference samples distributed in May 1995-T-135 (trace constituents), M-134 (major constituents), N-45 (nutrients), N-46 (nutrients), P-24 (low ionic strength), Hg-20 (mercury), and SED-5 (bed material): U.S. Geological Survey Open-File Report 95-395, 135 p.

PerkinElmer, 2010, Winlab 32 Software, version 4.0: Waltham, Mass., PerkinElmer.

Thompson, Michael, and Walsh, J.N., 1983, A handbook of inductively coupled plasma spectrometry: Glasgow, Scotland, United Kingdom, Blackie \& Son Ltd, p. 16-36.

U.S. Geological Survey, 2006, Collection of water samples (ver. 2.0): U.S. Geological Survey

Techniques of Water-Resources Investigations, book 9, chap. A4, September 2006, accessed January 6, 2014, at http://pubs.water.usgs.gov/twri9A4/.

U.S. Geological Survey, Standard reference sample project-Results of the Fall 2003 inter-laboratory comparison: U.S. Geological Survey, accessed December 30, 2013, at http://bqs.usgs.gov/srs/SRS_Fall03/F03results.htm.

Verplanck, P.L., Antweiler R.C., Nordstrom, D.K., and Taylor, H.E., 2001, Standard reference water samples for rare earth element determinations: Applied Geochemistry, v. 16, no. 2, p. 231-244.

Wanty, R. B., Wang, Bronwen, Vohden, Jim, Briggs, P. H., and Meier, A. H., 1999, Regional baseline geochemistry and environmental effects of gold placer mining operations on the Fortymile River, eastern Alaska: U.S. Geological Survey Open-File Report 99-328, p. 11.

Wilde, F.D., Radtke, D.B., Gibs, Jacob, and Iwatsubo, R.T., eds., 2004 with updates through 2009, Processing of water samples (ver. 2.2): U.S. Geological Survey Techniques of Water-Resources Investigations, book 9, chap. A5, April 2004, accessed January 6, 2014, at http://pubs.water.usgs.gov/twri9A5/.

Woodworth, M.T., and Connor, B.F., 2001, Results of the U.S. Geological Survey's analytical evaluation program for standard reference samples distributed in April 2001: U.S. Geological Survey Open-File Report 2001-287, p. 110. 


\section{Appendix 1. Generation of Multicomponent Spectral Fitting (MSF) and Interelement Correction Factors (IEC) Correction Equations}

\section{Required solutions:}

- Calibration blank (2 percent $\mathrm{HNO}_{3}$ blank)

- Low-level standard (lowest standard in method calibration, contains all elements of interest)

- $500 \mathrm{mg} / \mathrm{L}$ pure Ca Standard (Inductively coupled plasma [ICP] grade standard)

- $500 \mathrm{mg} / \mathrm{L}$ pure Mg Standard (ICP grade standard)

- $500 \mathrm{mg} / \mathrm{L}$ pure Al Standard (ICP grade standard)

- $200 \mathrm{mg} / \mathrm{L}$ pure Fe Standard (ICP grade standard)

- Mixed Interferent Check Solution (ICS); mix Ca, Mg, Al, Fe at above levels

- $1 \mathrm{mg} / \mathrm{L}$ single element solutions of Ag, Al, As, B, Ba, Be, Bi, Ca, Cd, Co, Cr, Cu, Fe, K, Li, Mg, Mn, Mo, Na, Ni, P, Pb, S, Sb, Se, Si, Sr, Th, Ti, Tl, U, V, W, Zn, Zr

Open the auto-analysis window; save the data to a file titled: your method name_MSF. This is important if you want to edit your MSF model in the future. To recall MSF models to edit them, all the samples used to create the model must be in the open results file.

Load auto-sampler and Create Sample information file:

\begin{tabular}{cl}
\hline $\begin{array}{c}\text { Autosampler } \\
\text { position }\end{array}$ & \multicolumn{1}{c}{ Sample name } \\
\hline 21 & Calibration blank \\
22 & Standard 1 (Name specified in method) \\
23 & $\mathrm{Ca} 500 \mathrm{mg} / \mathrm{L}$ \\
24 & $\mathrm{Mg} 500 \mathrm{mg} / \mathrm{L}$ \\
25 & $\mathrm{Al} 500 \mathrm{mg} / \mathrm{L}$ \\
26 & $\mathrm{Fe} 200 \mathrm{mg} / \mathrm{L}$ \\
27 & $\mathrm{ICS}(\mathrm{mixed}$ interferent solution) \\
28 & $\mathrm{Ag} 1 \mathrm{mg} / \mathrm{L}$ \\
29 & $\mathrm{Al} 1 \mathrm{mg} / \mathrm{L}$ \\
30 & $\mathrm{~B} 1 \mathrm{mg} / \mathrm{L}$ \\
$31-$ end & Rest of single element $1 \mathrm{mg} / \mathrm{L}$ solutions each in separate vials \\
\hline
\end{tabular}

Optimize instrument and perform a $\mathrm{Hg}$ realign before proceeding with analysis. Performing a $\mathrm{Hg}$ realignment now will ensure that any subsequent drift can be corrected for, by simply doing a daily $\mathrm{Hg}$ realignment, and the MSF models will continue to be valid. Shifting peaks will invalidate MSF models.

Analyze each of the solutions using the analytical method you are determining MSF models for (for example, water02TT 20120711).

Once the analysis has completed, shut off the instrument. Use the "Examine Spectra" tool in the WinLab version 4.0 software and reprocess all of the data to validate corrections. The following are the general steps used to finalize the method and add interferent corrections.

\section{Step 1:}

Use examine spectra window to align wavelengths, and set background points. While doing this, make note of the elements and wavelengths that show problems to be corrected by MSF. Note: the window will show spectra for all solutions overlayed so you can see where potential interferences are. 


\section{Step 2:}

Switch to the MSF model builder in the examine spectra tool and begin building MFS models for elements that showed spectral interferences. MSF does not correct for direct spectral overlap, so if direct overlaps are observed, alternative wavelengths should be used.

Once the MSF models have been created, use the reprocessing mode of the software to reprocess the data collected and review changes to the data. Use the ICS or mixed matrix sample run to evaluate the effect of the corrections. Results for analyte elements should be very close to zero for all elements, except for the matrix elements of $\mathrm{Ca}, \mathrm{Mg}, \mathrm{Al}$, and $\mathrm{Fe}$, which are contained in this solution.

See PerkinElmer WinLab version 4.0 Software Manual, Section 9, p. 388-402, for more detailed information. 